Johnson \& Wales University ScholarsArchive@JWU

Health \& Wellness Department Faculty

Publications and Research

College of Health \& Wellness

2017

\title{
Alcohol industry self-regulation: Who is it really protecting
}

Jonathan K. Noel

Johnson \& Wales University - Providence, Jonathan.Noel@jwu.edu

Zita Lazzarini

Katherine Robaina

Alan Vendrame

Follow this and additional works at: https://scholarsarchive.jwu.edu/health_fac

Part of the Medicine and Health Sciences Commons

\section{Repository Citation}

Noel, Jonathan K.; Lazzarini, Zita; Robaina, Katherine; and Vendrame, Alan, "Alcohol industry self-regulation: Who is it really protecting" (2017). Health \& Wellness Department Faculty Publications and Research. 43.

https://scholarsarchive.jwu.edu/health_fac/43 


\title{
Alcohol industry self-regulation: who is it really protecting?
}

\author{
Jonathan Noel', Zita Lazzarini', Katherine Robaina' \& Alan Vendrame ${ }^{2}$ \\ Department of Community Medicine and Health Care, University of Connecticut School of Medicine, Farmington, CT, USA' and Department of Psychiatry, Federal \\ University of São Paulo, São Paulo, Brazil $\left.\right|^{2}$
}

\begin{abstract}
Self-regulation has been promoted by the alcohol industry as a sufficient means of regulating alcohol marketing activities. However, evidence suggests that the guidelines of self-regulated alcohol marketing codes are violated routinely, resulting in excessive alcohol marketing exposure to youth and the use of content that is potentially harmful to youth and other vulnerable populations. If the alcohol industry does not adhere to its own regulations the purpose and design of these codes should be questioned. Indeed, implementation of alcohol marketing self-regulation in Brazil, the United Kingdom and the United States was likely to delay statutory regulation rather than to promote public health. Moreover, current selfregulation codes suffer from vague language that may allow the industry to circumvent the guidelines, loopholes that may obstruct the implementation of the codes, lax exposure guidelines that can allow excessive youth exposure, even if properly followed, and a standard of review that may be inappropriate for protecting vulnerable populations. Greater public health benefits may be realized if legislative restrictions were applied to alcohol marketing, and strict statutory alcohol marketing regulations have been implemented and defended successfully in the European Union, with European courts declaring that restrictions on alcohol marketing are proportional to the benefits to public health. In contrast, attempts to restrict alcohol marketing activities in the United States have occurred through private litigation and have been unsuccessful. None the less, repeated violations of industry codes may provide legislators with sufficient justification to pass new legislation and for such legislation to withstand constitutional review in the United States and elsewhere.
\end{abstract}

Keywords Advertising, alcohol, alcohol industry, marketing, regulation, self-regulation.

Correspondence to: Jonathan K. Noel MPH, Department of Community Medicine and Health Care, UConn School of Medicine, 263 Farmington Avenue, MC 6325, Farmington, CT, USA 06030-6325. E-mail: jnoel@uchc.edu

Submitted 1 February 2016; initial review completed 17 February 2016; final version accepted 20 April 2016

\section{INTRODUCTION}

The International Center for Alcohol Policies (ICAP), an international non-profit organization funded by the alcohol industry [now called the International Alliance for Responsible Drinking (IARD)], has promoted self-regulation as an effective means of controlling alcohol marketing practices [1]. Recent reviews have indicated that selfregulated alcohol marketing codes are violated routinely, alcohol advertisements regularly contain content appealing to vulnerable populations, and youth populations are exposed to disproportionately large amounts of alcohol advertising [2,3]. Moreover, the World Health Organization (WHO) has concluded that industry self-regulation may result in loss of governmental policy control [4].

In contrast to ICAP's policy agenda, some countries have implemented and defended statutory alcohol marketing regulations successfully. Austria, Belgium, Finland, France, Germany and Ireland have banned spirits advertising on television [5]. France's Loi Évin restricts alcohol marketers to using only the name of the alcohol manufacturer, the brand name of the product and related product characteristics, and prohibits television advertisements for products having an alcohol content of greater than 2\% [6]. The Advertising Act of Ukraine stipulates that alcohol advertisements appearing on television or radio can only be broadcast from 11 p.m.-6 a.m. [7]. Thailand's Alcoholic Beverage Control Act states that alcohol advertisements may not directly or indirectly promote consumption, imply that drinking alcohol is beneficial or show the product or its packaging [8]. Finland, as of 2015, has banned all Finnish alcohol producers from advertising on social media [9].

Although ICAP and other industry groups promote self-regulation, they do not state the purpose and basic 
assumptions underlying the creation of their codes. This paper uses legal documents and precedents to examine these questions as well as highlights flaws in current selfregulated alcohol marketing codes, discusses potential limits on alcohol marketing regulations and identifies previous litigation against alcohol marketing practices.

\section{Self-regulated alcohol marketing codes: assumptions and purpose}

As currently constructed, self-regulated alcohol marketing codes contain a number of implicit and explicit assumptions that may reflect their purpose. For example, the adoption of marketing codes implies that restrictions on alcohol marketing are required. The inclusion of exposure restrictions for youth implies that individuals below the legal purchase age (LPA) should not be exposed to alcohol marketing, and ICAP's Guiding Principles, which serve as a 'model' self-regulatory alcohol marketing code, list pregnant women explicitly as a vulnerable population requiring protection [1]. We explored these assumptions and the purpose of the codes by investigating the genesis of current self-regulated alcohol marketing codes in the United States, the United Kingdom and Brazil.

\section{United States}

Discussions regarding the regulation of alcohol advertising in the United States began in the 1940s [10], and opponents of government regulation have used the First Amendment of the US Constitution successfully to assert commercial free speech rights on the basis that consumers need truthful information to make reasonable choices about advertised products (e.g. 44 Liquormart, Inc. v. Rhode Island) [11]. The Twenty-First Amendment (granting states jurisdiction over alcohol beverage commerce) and the Fifth Amendment (prohibition on discrimination) have also been utilized as constitutional defenses.

In 1985, before the US House of Representatives Subcommittee on Telecommunications, Consumer Protection and Finance, Stephen K. Lambright, the then Vice-President of Anheuser-Busch stated: 'Rather than imposing either counter-advertising or a total ban, we would request that the Congress accept our commitment to vigorous industry self-regulation' [12]. During the hearing, Lambright, William O'Shea, President of the Brewer's Association of America, and John De Luca, President of the Wine Association, stated repeatedly that advertising has no effect on youth while also describing how their self-regulated alcohol marketing codes protect children. When legislative hearings were unable to establish a definitive causal link between advertising and youth alcohol consumption, self-regulation was advanced as the primary alternative [13], resulting in the beer, wine and liquor sectors each having unique, self-imposed advertising codes of conduct.

In 1996, following a liquor advertisement aired by Seagram, the Distilled Spirits Council of the United States (DISCUS), the spirits industry's national trade association, ended a decades-long voluntary ban on the advertising of liquor products on television and radio, which had been in effect since 1936 and 1948 for radio and television, respectively. The action prompted fierce criticism. Representative Joseph Kennedy II introduced several bills attempting to restrict alcohol advertising (e.g. the Just Say No Act and the Comprehensive Alcohol Abuse Prevention Act) [14]; President Bill Clinton called on the Federal Communications Commission (FCC) to begin an investigation into liquor advertisements, and the FCC Chairman suggested that voluntary restraint was ineffective and a ban on liquor advertisements was needed [15]. He urged all television and radio stations to "just say no' to liquor advertising. The FCC inquiry was expanded to include beer advertisements after the Stroh Brewery Co. aired an advertisement during a MTV show targeted at teenage girls [16].

To reassure critics concerned about alcohol abuse and under-age drinking, DISCUS revised its voluntary Code of Good Practice in 1996. In place of the television and radio advertising ban, the revised code listed 26 provisions aimed at promoting responsible advertising, including restrictions on the use of cartoon characters popular among children, although producers could create their own characters [17]. The Beer Institute implemented a voluntary marketing code applicable to beer advertisements a year later [16].

\section{United Kingdom}

In the United Kingdom, the industry-sponsored 'social aspect' organization the Portman Group introduced its Code of Practice on the Naming, Packaging and Promotion of Alcohol Drinks (referred to herein as the UK Code) in April 1996 in response to public and government concern over alcopops, sweet-flavored alcoholic drinks often packaged in ways appealing to youth [18]. A year later, a survey of 700 children in seven schools showed that $59 \%$ drank alcopops, prompting the government to order an 'urgent' investigation [19]. The ministerial group investigating alcopops issued a statement demanding 'swift action' by the industry and warned that, if not satisfied, the group was 'prepared to go further'. 'It is essential that we protect our children from being ensnared into the downward spiral of alcohol abuse and crime', the statement added [20]. At the same time, a second edition of the UK Code was released that included firmer restrictions on advertisements, including a ban on references to illegal drugs, linking alcohol with sexual prowess, using actors under 
the age of 25 years and using artificially bright colors or child-like lettering. It also established an independent review panel [21]. The government steering group created to investigate the problem did not recommend an outright ban, in part because of the revamped UK Code. The code has since been revised five times, with the latest edition published in May 2013 [22].

\section{Brazil}

Although self-regulation of alcohol marketing predominates, the Brazilian mechanism differs from that used in the United States and United Kingdom. Instead of being created by the alcohol industry, self-regulation is defined, implemented and managed by the advertising industry's National Council for Self-Regulation in Advertising [Conselho Nacional de Autorregulamentacão Publicitária (CONAR)] and their Code of Self-Regulation in Advertising (CONAR code), which all industries pledge to follow [23]. In the 1970s, the federal government attempted to promulgate a law that would have required each advertisement to receive an 'In Agreement' stamp before dissemination. The CONAR code emerged as the industry's response. The idea came from the UK model and gained momentum at the hands of the biggest names in Brazilian advertising. By 1978, during the Third Brazilian Advertising Congress, CONAR obtained federal recognition of the CONAR code, convincing regulators to shelve the censorship project and trust that Brazil's advertising was mature enough to self-regulate. Others have concluded that self-regulation in Brazil has ensured commercial free speech rights and defended the interests of the advertising industry [24,25].

In 1985, a military dictatorship was replaced by a democracy. The current federal constitution, enacted in 1988, introduced a series of individual and collective rights, such as freedom of expression, as a means to limit possible state abuse. The Constitution also determined that alcohol advertisements should be regulated by law [26], which occurred in 1996 [27]. However, the Brazilian Congress yielded to strong alcohol industry lobbying and defined alcoholic beverages for advertising purposes as those with an alcohol concentration greater than 13 degrees of alcohol using the Gay-Lussac method of measurement, thus effectively eliminating beer and some wines from regulation. Since then, more than two dozen bills have been submitted by various parliamentarians attempting to correct the definition of alcoholic beverages for advertising purposes [28]. In our opinion, all have been unsuccessful due to alcohol industry lobbying efforts, which includes financing parliamentary political campaigns and donating millions of dollars to politicians each election cycle. More recently, the Attorney General of the Republic filed a lawsuit in the Brazilian Supreme Court seeking to force the National Congress to correct the concept of alcoholic beverages for advertising purposes so that it includes those with an alcohol concentration above 0.5 degrees Gay-Lussac; however, the lawsuit was ultimately dismissed by the Brazilian Supreme Court [29].

\section{Language, loopholes and gaps}

The language used in self-regulated alcohol marketing codes has been criticized for being vague and open to multiple interpretations, containing loopholes that undermine the effectiveness of guidelines at protecting vulnerable populations, having lax exposure guidelines and for the reference point used when determining code compliance [30]. Here, we use ICAP's Guiding Principles [1], the US Beer Institute's Advertising and Marketing Code [31], Diageo's Marketing Code [32] and correspondence received from the US Beer Institute during a complaint process to highlight what we believe are deficiencies.

\section{Vagueness}

In ICAP's Guiding Principles, Section 5: 'The effects of alcohol' contains guidelines that focus on prohibiting the portrayal of alcohol as enhancing abilities, whether social, sexual or academic [1]. Guideline 5.3 states, Alcohol beverage marketing communications should not... suggest that alcohol beverages can enhance physical, sporting, or mental ability'. There are at least two ways to interpret this guideline. An interpretation favoring the alcohol industry would be that a direct, explicit, causal link between the product and enhanced ability needs to be shown in order for this guideline to be violated. Conversely, an interpretation favoring public health authorities would be that any association between the product and any type of ability enhancement should be considered a violation because a viewer may perceive the association as having a causal impact on an individual's abilities and behavior.

\section{Loopholes}

In our opinion, the US Beer Institute's Advertising and Marketing Code contains a series of loopholes that undermine the impact and reach of the code. First, "These guidelines do not apply to educational materials, [or] messages of a non-brand specific nature...' [31]. This implies that corporate social responsibility messages are not covered by this code, allowing companies to promote their products indirectly without restriction. The code also states that the 'guidelines do not apply to... materials or messages designed specifically to address issues of alcohol awareness, abuse, drunk driving, underage drinking, or overconsumption', without specifying the extent or type of anti-drinking statements necessary to meet this requirement [31]. The statement is particularly important due to the proliferation of 'responsible drinking' messages that appear at the end of television or radio advertisements, 
and within the fine print of print advertisements. In the extreme, the industry may consider these messages sufficient to identify the entire advertisement as addressing excessive alcohol consumption and the entirety of the Beer Institute's code may then no longer apply. Furthermore, Diageo's Marketing Code appears to contain a significant loophole stating explicitly that their advertisements may be appealing to youth [32]. They simply prohibit themselves from creating advertisements that appeal primarily to this demographic.

\section{Exposure guidelines}

ICAP's Guiding Principles specify that alcohol advertisements should be placed in media only where at least 70\% of the audience consists of legal drinkers [1]. This value matches the proportion of individuals above the legal drinking age in the United States according to the 2000 census [33]. The US Beer Institute code uses a standard of $71.6 \%$, which uses the same value from the 2010 census $[31,34]$. These cut-offs are used under the premise that any programming that has an audience with a higher proportion of adults is unlikely to be attractive to youth, but there are several issues that these cut-off values do not consider.

First, the values are not adjusted for those minors who are highly unlikely to watch adult-oriented programming, specifically the under 5-year-old population, which accounted for $6.8 \%$ of the total US population in 2010 [34]. Moreover, advertisement buying guidelines for the industry may only require audience composition data for the $12+$ or $18+$ population when purchasing advertising space, excluding 0-11-year-olds or 0-17-year olds from exposure calculations [35]. Secondly, the lack of a maximum number of underage viewers allowed in an audience means that high levels of exposure can still occur even though the audience is well within the industry's threshold [36]. Thirdly, cut-off values based on the US population are not applicable to countries where the LPA is lower or in countries with different population demographics.

\section{Standard of review}

According to the US Beer Institute code, alcohol producers should use the perspective of a reasonable adult consumer when making marketing and advertising decisions [31], but this standard may be inappropriate. The reasonable adult standard assumes that all advertisements are perceived by a typical member of the population and disregards the exposure and perceptions of potentially vulnerable subgroups. Youth, for example, are listed explicitly as a vulnerable population in many codes, yet are expected to perceive advertisements as reasonable adults. It is plausible that other vulnerable populations, such as pregnant women, alcoholics or ethnic minorities, would also perceive alcohol advertisements differently because the perceptions of risk may not be communicated using culturally appropriate methods for that demographic [37]. The guidelines also fail to define who a 'typical' person is, which may or may not be someone with a history of chronic disease, mental illness or substance abuse.

\section{Statutory alcohol marketing regulations}

If statutory regulations on alcohol marketing are enacted, legal challenges from the alcohol industry are likely to follow. In the United States, commercial free speech has been afforded substantial First Amendment protections since 1975 [38], and regulatory agencies have preferred to allow the market-place to self-regulate commercial speech since the 1980s [39]. However, commercial free speech is not absolute, although any regulation will be subject to the four-part ‘Central Hudson' test (Table 1) [40]. In these cases, the government carries the burden of proof, and courts are instructed to use an intermediate level of scrutiny, although conservative justices have advocated using strict scrutiny when truthful information is involved $[41,42]$. US experiences are not always transferable to other countries, however. Indeed, severe restrictions on alcohol marketing have been implemented and upheld in other countries. In France, the Loi Évin stipulates a partial ban on alcohol advertisements with very few exceptions [7], and the effects of the law extend beyond brand-specific advertising [43]. Loi Évin inevitably restricts sports teams and stadium operators from contracting with alcohol companies and imposes additional costs on broadcast transmitters who must remove alcohol references before sports broadcasts are shown in France. These consequences are felt by entities within and outside of France. Consequently, the law has been challenged multiple times.

In Bacardi-Martini SAS, Cellier des Dauphins v. Newcastle United Football Company Ltd, Bacardi challenged the Loi Évin in the United Kingdom on grounds of interference with sponsorship contracts and that such interference was contrary to provisions within the European Community (EC) treaty [44]. EC Courts did not provide a definitive ruling on the matter, stating that the UK courts did not provide sufficient justification for how French legislation

Table 1 The four-part 'Central Hudson' test.

Question

Part 1 Is the activity unlawful and is the speech false, deceptive or misleading?

Part 2 Is the government interest substantial?

Part 3 Does the regulation of commercial speech directly advance the state interest?

Part 4 Is the regulation no more extensive than necessary? 
can influence their decisions. In Commission of the European Communities v. French Republic, the court determined that the Loi Évin was in conflict with the freedom to provide services provision, which is a fundamental right, but that this right may be limited for the purposes of protecting public health [45]. Furthermore, the Court expressly ignored the burden of extra costs imposed on broadcast transmission companies, choosing only to focus on the issue of party contracts, and showed deference to national legislative priorities. This rationale for upholding the Loi Évin in EC Courts provides a precedent for the expansion of strict, statutory regulations on alcohol marketing practices in EU member states. However, the Courts' deference to national priorities can also provide an avenue for EU regulations to be overturned which, for example, occurred in Sweden [46].

\section{Legal challenges against alcohol producers}

In the United States, a handful of lawsuits against alcohol producers have been filed seeking monetary or injunctive relief. These suits have met with little success. In Guglielmi v. Anheuser-Busch, Guglielmi sought a permanent injunction against Anheuser-Busch to modify their advertising practices [47]. The lawsuit was dismissed by the courts with prejudice. In Kreft v. Adolph Coors, a complaint alleging damages due to alcohol advertisements encouraging underage children to consume alcoholic beverages was dismissed because no injury to the plaintiffs was shown; the court awarded the defendants attorney fees [48]. Complaints against Zima, Anheuser-Busch and Coors have also been dismissed for either lack of standing or failure to show injury [49-52]. Guglielmi may have provided a basis for future public health litigation, however. Guglielmi stated that the lawsuit was in the 'public interest' yet no public agencies joined as plaintiffs, implying that state or federal agencies are required for litigation to proceed [47].

\section{Shifting away from self-regulation}

The presumption of self-regulated alcohol marketing codes is that subpopulations exist that are considered particularly vulnerable to alcohol marketing practices, and these populations should not be exposed to or be targeted by alcohol marketing. However, because youth exposure to alcohol marketing in countries where self-regulation predominates continues to be high and alcohol producers appear to violate the content guidelines of self-regulated alcohol marketing codes routinely [2], a plausible alternative explanation for the continued promotion of self-regulation by the alcohol industry is to delay statutory regulation, as suggested by the experiences in the United States, United Kingdom and Brazil. Indeed, we were unable to find documentation that alcohol producers stated explicitly that a marketing code was being implemented to protect youth or other vulnerable populations.

Interestingly, self-regulation has worked for some industries. The forestry industry established the Forest Stewardship Council to promote responsible management of forests when governments failed to do so, and the fishing industry established the Marine Stewardship Council to protect global fish stocks [53]. These selfregulatory measures were adopted successfully because the industries determined that there was economic benefit from following voluntary guidelines. In contrast, self-regulated marketing codes implemented in the tobacco and breast milk substitute industries failed $[53,54]$, leading ultimately to strict statutory legislation at the national and international levels $[55,56]$. Here, effective and enforced voluntary restrictions may have been seen as economically detrimental.

Repeated, blatant violations of self-regulated alcohol marketing codes can provide government regulators with an opportunity to use current laws to restrict marketing practices and provided legislators with a justification for passage of new laws, and 'legal scholars recognize that the failure of ethical norms to deter behavior that is widely regarded as unacceptable is a classic trigger for the imposition of legal norms' [57]. More bluntly, the alcohol industry invites direct legal regulation by ignoring the need for better adherence to the industry's own stated controls.

A number of countries have already imposed statutory restrictions on marketing activities, and in the European Union these restrictions have withstood legal challenges from the alcohol industry. However, any new restrictions will probably be met with additional legal challenges. Although tough marketing restrictions among EU member states may not violate EU treaties, legislation must still $\backslash$ surrvive country-specific constitutional review. In the United States, the environment for passage of alcohol marketing restrictions is difficult. Alcohol regulations must be defined narrowly and tailored to address specific issues among specific populations. Moreover, any attempts at using the litigation process to restrict alcohol marketing activities will require public agencies at the local, state or federal levels to be plaintiffs in order for any such lawsuit to proceed.

\section{Declaration of interests}

None.

\section{Acknowledgements}

This is a one of a series of papers published in a Supplement to Addiction entitled: "The Regulation of Alcohol Marketing: From Research to Public Health Policy.” This supplement was published with financial support from Alcohol Research UK and the Institute of Alcohol Studies. 
Preliminary versions of the majority of these manuscripts were first presented at a meeting organized by the Pan American Health Organization.

\section{References}

1. International Center for Alcohol Policies. Guiding Principles: Self-Regulation of Marketing Communications for Beverage Alcohol. Washington, DC, USA: 2011. Available at: http:// www.icap.org/LinkClick.aspx?fileticket $=y$ RzKnnECzO0\%3d\& tabid=105 (accessed 14 December 2014) (Archived at http:// www.webcitation.org/6fUabvYWa).

2. Noel J. K., Babor T. F., Robaina K. Industry self-regulation of alcohol marketing content and exposure: a systematic review. Addiction 2017; 112(Suppl. 1): 28-50.

3. Hastings G. Failure of self regulation of UK alcohol advertising. BMJ 2010; 340: b5650.

4. World Health Organization (WHO). WHO Expert Committee on Problems Related to Alcohol Consumption. Second Report. WHO Technical Series, 944. Geneva: WHO Press; 2007. Available at: http://www.who.int/substance_abuse/expert_ committee_alcohol_trs944.pdf (accessed 15 November 2014) (Archived at http://www.webcitation.org/6fUalsYOg).

5. Institute of Alcohol Studies. Alcohol advertising in the European Union. London, UK: 2013. Available at: http://www. ias.org.uk/Alcohol-knowledge-centre/Marketing/Factsheets/ Alcohol-advertising-in-the-European-Union.aspx (accessed 25 November 2014) (Archived at http://www.webcitation. org/6fUaoURFi).

6. LOI relative à la lutte contre le tabagisme et l'alcoolisme 1991. Pub. L. No. 91-32. Available at: https://www.legifrance.gouv. fr/affichTexte.do?cidTexte=JORFTEXT000000344577\&cate gorieLien=id (accessed 24 June 2016) (Archived at http:// www.webcitation.org/6iVOj5BFq).

7. Law of Ukraine on Advertising 1996. Pub. L. No. 271/96-VR. Available at: http://www.wipo.int/wipolex/en/text.jsp?file_ $\mathrm{id}=187714$ (accessed 24 June 2016) (Archived at http:// www.webcitation.org/6iVOyOOC8).

8. Alcohol Control Act 2008. Vol.125, Part 33a. Available at: http://www.thaiantialcohol.com/en/uploads/files/alcohol_ control_act.pdf (accessed 24 June 2016) (Archived at http:// www.webcitation.org/6iVPAkfYI).

9. Suomen Yleisradio (YLE). Government imposes further restrictions on alcohol advertising. 27 February 2014. Available at: http://yle.fi/uutiset/government_imposes_further _restrictions_on_alcohol_advertising/7112320 (accessed 8 January 2015) (Archived at http://www.webcitation.org/6fU asNO5X).

10. Pennock P. E. Advertising Sin and Sickness. DeKalb, IL: Northern Illinois University Press; 2007.

11. 44 Liquormart, Inc. v. Rhode Island (1996) 517 U.S. 484. Available at: https://supreme.justia.com/cases/federal/us/51 7/484/ (accessed 24 June 2016) (Archived at http://www. webcitation.org/6iVPNimqF).

12. Beer and wine advertising: impact of electronic media. Hearing before the Subcommittee on Telecommunications, Consumer Protection, and Finance of the Committee on Energy and Commerce of the House of Representatives. 99th Congress. 21 May 1985. Available at: http://files.eric. ed.gov/fulltext/ED263489.pdf (accessed 12 December 2014) (Archived at http://www.webcitation.org/6fUbbNlcl).

13. Starek R. The ABCs at the FTC: Marketing and Advertising to Children. Speech on Advertising and Promotion Law 1997.
Minnesota Institute of Legal Education, Minneapolis, MN, USA: 1997. Available at: http://www.ftc.gov/public-statements/1997/07/abcs-ftc-marketing-and-advertising-children (accessed 12 December 2014) (Archived at http://www. webcitation.org/6fUbhmWH0).

14. Kennedy J. P. Congressional Record 143: 43. Proceedings and debates of the 105th Congress, First Session. House of Representatives. 14 April 1997. Available at: https://www. congress.gov/crec/1997/04/14/CREC-1997-04-14.pdf (accessed 12 January 2015) (Archived at http://www.webcitation. org/6fUblVzgO).

15. Television Digest Staff. Hundt, Quello dispute on liquor ads. Television Digest 25 November 1996.

16. Anonymous A better beer ad code. Advert Age 1997; 68: 30.

17. Beatty S. Hard-Liquor Industry in the U.S. Votes to Rescind Ban on TV Ads. Wall Street Journal 11 November 1996.

18. Portman Group. History and Mission. London, UK: 2014. Available at: http://www.portmangroup.org.uk/about (accessed 4 January 2015) (Archived at http://www. webcitation.org/6fUbq3wYU).

19. Independent Staff. Ministers launch alcopops inquiry. Independent. 17 May 1997. Available at: http://www.independent.co.uk/news/ministers-launch-alcopops-inquiry1261890.html (accessed 4 January 2015) (Archived at http://www.webcitation.org/6fUbxmtGb).

20. The Herald Scotland. Drinks industry is warned on alcopops. 23 May 1997. Available at: http://www.heraldscotland.com/ news/12326193.Drinks_industry_is_warned_on_alcopops/ (accessed 12 December 2014) (Archived at http://www. webcitation.org/6fUc4tWrJ).

21. British Broadcasting Corporation (BBC). Double Crackdown on Teenage Drinkers. BBC Politics. 1997. Available at: http:// www.bbc.co.uk/news/special/politics97/news/07/0717/alcopops. shtml (accessed 10 November 2014) (Archived at http:// www.webcitation.org/6fUcEkRG3).

22. Portman Group. Code of Practice on the Responsible Naming, Packaging and Promotion of Alcoholic Drinks-fifth edn. London, UK: 2013. Available at: http://regulationforum.org/ docs/presentations/2013/Regulation\%20Symposium $\% 20$ March13.pdf (accessed 12 December 2014) (Archived by WebCite ${ }^{\circledR}$ at http://www.webcitation.org/6fUcIppM1).

23. Conselho de Auto-Regulamentação Publicitária. Código brasileiro de auto-regulamentação Publicitária. São Paulo, Brazil: 2014. Available at: http://www.conar.org.br (Archived at http://www.webcitation.org/6fUchc5GA) (accessed 2 November 2014).

24. Vendrame A., Pinsky I. Ineficácia da autorregulamentação das propagandas de bebidas alcoólicas: uma revisão sistemática da literatura internacional. Rev Bras Psiquiatr 2011; 33: 196-202.

25. Vendrame A., Pinsky I., Silva R. S., Babor T. Assessment of self-regulatory code violations in Brazilian television beer advertisements. J Stud Alcohol Drugs 2010; 71: 445-51.

26. Constitution of the Federative Republic of Brazil 1988.

27. Brazilian Law No. 9.294 1996. Available at: http://www. tobaccocontrollaws.org/files/live/Brazil/Brazil\%20-\%20Law \%20No.\%209.294.pdf (accessed 24 June 2016) (Archived at http://www.webcitation.org/6iVPZGmd1).

28. Narchi E. O álcool nos meios de comunicação. Audiência Pública realizada pelo Conselho de Comunicação Social do Congresso Nacional. In: Exposição do CONAR. Brasília, Brazil: 2005. Available at: http://www.senado.gov.br (accessed 15 November 2014) (Archived at http://www.webcitation.org/ $6 f(c m R f i A)$. 
29. Acao Direta de Inconstitucionalidade por Omissao ADO 22 [Unconstitutional Direct Action by Omission ADO 22] (2015). Supremo Tribunal Federal ADO 22 (2015). Available at: http://www.stf.jus.br/portal/processo/verProcessoAnda mento.asp (accessed 22 February 2016) (Archived at http:// www.webcitation.org/6fUb0NkWc).

30. Babor T., Caetano R., Casswell S., Edwards G., Giesbrecht N., Graham K. et al. Alcohol: No Ordinary Commodity, 2nd edn. New York: Oxford; 2010.

31. US Beer Institute. Beer Institute Advertising and Marketing Code. Washington, DC, USA: 2015. Available at: http:// www.beerinstitute.org/assets/uploads/general-upload/2015Beer-Ad-Code-Brochure.pdf (accessed 12 December 2015) (Archived at http://www.webcitation.org/6fUcpsBhQ).

32. Diageo. Diageo Marketing Code: Promoting Responsible Drinking. Norwalk, CT, USA: 2012. Available at: http:// www.drinkiq.com/en-US/Documents/Diageo-Marketing-CodeJuly\%202012_US.pdf (accessed 20 November 2014) (Archived at http://www.webcitation.org/6fUb3eDmB).

33. US Census Bureau. Table DP-1. Profile of General Demographic Characteristics: 2000. Washington, DC, USA: 2000. Available at: http://censtats.census.gov/data/US/01000.pdf (accessed 15 December 2014) (Archived at http://www. webcitation.org/6fUb86S78).

34. Howden L. M., Meyer J. A. Age and Sex Composition: 2010. U. S. Department of Commerce, Economics and Statistics Administration, US Census Bureau, Washington, DC, USA: 2011. Available at: http://www.census.gov/prod/cen2010/briefs/ c2010br-03.pdf (accessed 12 December 2014) (Archived at http://www.webcitation.org/6fUcwD6Dn).

35. US Beer Institute. Buying Guidelines for the Implementation of Section 3c of the Beer Institute Advertising and Marketing Code. Washington, DC: 2011. Available at: http://www. beerinstitute.org/assets/uploads/general-upload/AdCodeBuying Guidelines_w-LogoFINAL2011.pdf (accessed 12 December 2014) (Archived at http://www.webcitation.org/6fUcyndTj).

36. Center on Alcohol Marketing and Youth. Youth Exposure to Alcohol Advertising on Television, 2001-2009. Baltimore, MD, USA: 2012. Available at: http://www.camy.org/research/Youth_Exposure_to_Alcohol_Ads_on_TV_Growing Faster_Than_Adults/_includes/TVReport01-09_Revised_712.pdf (accessed 29 October 2014) (Archived at http://www. webcitation.org/6dqu4XV1T).

37. Babor T. F., Robaina K., Noel J. K. Vulnerability to alcoholrelated problems: a policy brief with implicationsfor the regulation of alcohol marketing. Addiction 2017; 112(Suppl. 1): 94-101.

38. Bigelow v. Virginia (1975) 421 U.S. 809, 826.

39. Younger S. Alcohol beverage advertising on the airwaves: Alternatives to a ban or counteradvertising. UCLA Law Review 1987; 34: 1139-94.

40. Central Hudson Gas v. Public Service Commission (1980) 447 U.S. $557,563$.

41. Florida Bar v. Went for It, Inc. (1995) 515 U.S. 618, 623. Available at: https://supreme.justia.com/cases/federal/us/ 515/618/ (accessed 24 June 2016) (Archived at http:// www.webcitation.org/6iVPq24Pu).

42. Edenfield v. Fane (1993) 507 U.S. 761, 770-71. Available at: https://supreme.justia.com/cases/federal/us/507/761/ (accessed 24 June 2016) (Archived at http://www. webcitation.org/6iVPuBB1M).

43. Cozens C. EC to challenge French alcohol ad ban. Guardian. 26 July 2001. Available at: http://www.theguardian.com/ media/2001/jul/26/advertising (accessed 12 January 2015) (Archived at http://www.webcitation.org/6fUdCXMtf).
44. Graduaksaite J. The advertising appeal of sports and the legal limits of the incorporation of sports in advertising. Entertainment and Sports Law Journal. 2010. Available at: http://go. warwick.ac.uk/eslj/issues/volume8/number1/gradauskaite/ (accessed 8 December 2015) (Archived at http://www. webcitation.org/6fUdG6ESC).

45. Hatzopoulos V., Do T. U. The case law of the ECJ concerning the free provision of services: 2000-2005. Common Market Law Rev 2006; 43: 923-91.

46. de Bruijn A. Legal possibilities of a comprehensive alcohol advertising ban in Europe. European Centre for Monitoring Alcohol Marketing, Utrecht, the Netherlands: 2011. Available at: http://old.drugsandalcohol.ie/15389/1/fs-20110616-legal-possibilities_online $\% 5 \mathrm{~B} 1 \% 5 \mathrm{D}$.pdf (accessed 5 January 2015) (Archived at http://www.webcitation.org/6fUdK2agk).

47. Guglielmi v. Anheuser-Busch Cos, Inc. (US Dist. Ct., 2005) No CV-04-594-ST, WL 300064.

48. Kreft v. Adolph Coors Company (CO Court of Appeal, Div I, 2007) No. 05CA2315, 170 P.3d 854. Available at: https:// www.courtlistener.com/opinion/2600344/kreft-v-adolphcoors-co/ (accessed 24 June 2016) (Archived at http://www. webcitation.org/6iVQFzcXZ).

49. Hakki v. Zima Co. (D.C. Ct. App. 2007) No. 06-CV-467, 926 A.2d 722. Available at: https://www.courtlistener.com/opinion/1910311/hakki-v-zima-co/ (accessed 24 June 2016) (Archived at http://www.webcitation.org/6iVQY4Tsk).

50. Goodwin v. Anheuser-Busch Cos. (Cal. Sup. Ct., 2005) No. BC310105, 2005 WL 280330. Available at: http://appellate cases.courtinfo.ca.gov/search/case/disposition.cfm?dist $=2 \&$ doc _id=1120754\&div=1\&doc_no=B182095 (accessed 24 June 2016) (Archived at http://www.webcitation.org/6iVQwXILD).

51. Eisenberg v. Anheuser-Busch, Inc. (N.D. Ohio, 2006) No. 1:04-CV-1081, 2006 WL 290308. Available at: https:// www.courtlistener.com/opinion/2975380/eisenberg-v-anhe user-busch-inc/ (accessed 24 June 2016) (Archived at http:// www.webcitation.org/6iVR4atRk).

52. Tomberlin v. Coors Co. (WI Court of Appeals 2007) No. 2006AP1302, 2007 WI App 251, 742 N.W.2d 74. Available at: https://www.wicourts.gov/ca/opinion/DisplayDocument. html?content $=\mathrm{html} \&$ seqNo=30706 $($ accessed 24 June 2016) (Archived at http://www.webcitation.org/6iVRIxMbK).

53. Sharma L. L., Teret S. P., Brownell K. D. The food industry and self-regulation: standards to promote success and to avoid public health failures. Am J Public Health 2010; 100: 240-6.

54. Brady J. P. Marketing breast milk substitutes: problems and perils throughout the world. Arch Dis Child 2012; 97: 529-32.

55. Convention Secretariat, WHO Framework Convention on Tobacco Control. 2014 global status report on implementation of the WHO Framework Convention on Tobacco Control. World Health Organization, Geneva, Switzerland: 2014. Available at: http://www.who.int/fctc/reporting/ 2014globalprogressreport.pdf (accessed 29 January 2016) (Archived at http://www.webcitation.org/6fUdYKYO7).

56. United Nations International Children's Emergency Fund (UNICEF). National Implementation of the International Code of Marketing of Breastmilk Substitutes (April 2011). New York, NY, USA: 2011. Available at: http://www.unicef.org/ nutrition/files/State_of_the_Code_by_Country_April2011. pdf (accessed 29 January 2016) (Archived at http://www. webcitation.org/6fUdbwqbO).

57. Studdert D. M., Mello M. M., Brennan T. A. Financial conflicts of interest in physicians' relationships with pharmaceutical industry - self-regulation in the shadow of Federal prosecution. N Engl J Med 2004; 351: 1891-900. 